\title{
Vývoj trestání deliktu rouhání a urážky Boha v českých zemích
}

\author{
Karel Malý
}

Kontaktnie-mail: maly@prf.cuni.cz

The Development of the Crime of Blasphemy and Insult to God in the Czech Lands

\begin{abstract}
:
The article deals with the issue of the crime of blasphemy and insult to God in a wide time horizon, from the beginnings of the spread of Christianity to the middle of the 20th century. In addition to historical developments, it also maps the factual nature of these offenses and their entrenchment in criminal codes. It reflects the relationship between church and state and their mutual intersections in the exercise of judicial power. The article further analyzes the development of criminal law protection of the church. The greatest attention is paid to medieval and modern (Theresian and Josephine) legislation.
\end{abstract}

Keywords: torts against God; church and state; judiciary; criminal law; canon law

Klíčová slova: delikty proti bohu; církev a stát; soudnictví; trestní právo; kanonické právo

DOI: $10.14712 / 2464689 X .2021 .17$

Nejvyšší představitel katolické církve v České republice, kardinál Dominik Duka, podal žalobu k Městskému soudu v Brně a po jejím zamítnutí ke Krajskému soudu tamtéž, ve které tvrdil, že divadelní hry uváděné na festivalu Divadelní svět porušily jeho základní práva a svobody tím, že hrubým způsobem urážely křest’anství, katolickou církev a osobnosti všech věřících. Také toto odvolání bylo zamítnuto a obhájce žalovaného, Centra experimentálních divadel, spokojeně konstatoval, že se panu kardinálovi nepodařilo „oklikou dostat do českého právního řádu delikt blasphemie, rouhačství..."1

Tento delikt skutečně již v našem právním řádu neexistuje a právní řád opravdu neposkytuje církvím a věřícím v tomto smyslu právní ochranu, a ti tak zřejmě musí snášet i veřejně

$1 \quad$ Viz Deník Právo, 21. 11. 2019. 
realizované brutální urážky své víry a náboženského vyznání, jak ukázal právě brněnský príklad. To je také, jak se domnívám, dobrým důvodem pokusit se sledovat složitý vývoj trestání deliktu rouhání a trestně právní ochrany církve v našich právních dějinách.

\section{I.}

Počátky deliktu rouhání a urážky Boha jsou spojeny s počátkem křest’anství ve středověké Evropě a s úlohou církve ve společnosti, kde byla církev nejen spojencem státu při budování a upevňování státní moci, respektive sakrální podoby postavení panovníka, ale její učení a právo nahrazovalo zejména v počátcích státu absenci světského práva a iniciovalo jeho vytváření; podobně jako kultivovalo společnost včetně její ekonomiky, prrinášelo jí základy středověké učenosti, a byla to církev, která iniciovala zakládání univerzit.

Ochranou církve chránil tak středověký stát důležitou oporu své rané existence a středověkému věřícímu člověku dával víru v posmrtné spasení a zdůvodnění jeho místa v hierarchicky strukturované společnosti. Ochrana církve byla proto samozřejmostí nepochybně ochotně přijímanou. Delikty stíhané světským právem jsou často současně porušením božího přikázání, jsou proviněním vi̊či Bohu, stejně tak jako urážky světského panovníka. Proto také nalézáme v podstatě stejné označení urážky Boha a krále - crimen laese divine maiestatis, crimen laese maiestatis. ${ }^{2}$ Toto chápání deliktu jako provinění vůči Bohu, kdy pak i výkon trestu je především prostředkem vyrovnání s Bohem a formou nápravy hříchu deliktem spáchaného, se postupně mění s proměnou státu, společnosti a práva v raném novověku a posléze v souvislosti s vlivem osvícenství na podobu práva a na modernizaci státu. Právě proto je, dle mého hlediska, důležité zkoumat postupnou proměnu trestněprávních předpisů stíhajících útoky proti církvi, nebot' tento proces odráží proměnu společnosti, právního řádu a společenského vědomí.

Vliv církve ve středověké společnosti můžeme pozorovat především při uplatňování a výkonu práva, v soudním procesu. Je to typické především v počátcích středověkých států, kdy se uplatňuje iracionální forma důkazu božím soudem - ordálem -, který vytlačuje krevní mstu jako formu vyrovnání s pachateli trestného činu a snižuje riziko soukromých válek a záští, které oslabovaly stabilitu středověké společnosti, a současně tak posiluje autoritu práva a jeho vykonavatelů, především pak panovníka. ${ }^{3}$

Př́ísahající strany v ordálovém procesu se obracely k Bohu, dovolávaly se jeho pomoci, skládaly svou při v jeho ruce. Ostatně typická forma důkazů v tomto raně akuzačním (obžalovacím) procesu také přenášela rozhodnutí ze soudce na Boha, který měl svou pomocí rozhodnout o pravdivosti tvrzení stran. ${ }^{4}$

A tak vliv církve nalézáme především v důkazním řízení. Připomeňme tu např. přísahu obviněného a svědků, která se odvolává na Boha, obrací se k němu, má často očistnou podobu a vyžaduje přesné přednesení přísežné formule, přičemž pochybení znamenalo

2 Srov. MALÝ, K. Zločin urážky panovníka v českém právu doby předhusitské. Právněhistorické studie, 1971, roč. 15 , s. $141-164$.

3 Srov. MALÝ, K. Dějiny českého a československého práva do roku 1945. 4. přepracované vydání. Praha: Leges, 2010, s. 112, Církevní právo.

4 Tamtéž, s. 115-118, k středověkým ordálům srov. zvl. SCHILD, W. Das Gottesurteile. In: HINCKELDEY, Ch. (Hrsg.). Justiz in alter Zeit. Band IV. Rothenburg ob der Tauber: Kriminalmuseum Rothenburg, 1989, s. $225-239$. 
ztrátu důkazu a pře, což můžeme u nás doložit již od 11. století, jak dokazují Dekreta Břetislavova vyhlášená zřejmě roku 1039, která se snažila odstranit krevní mstu. ${ }^{5}$

Současně nutno však říci, že sama církev zaujímala k ordálům, kterých se museli kněží osobně účastnit, negativní postoj. Tak již čtvrtý lateránský koncil zakázal v roce 1215 kněžím účast na ordálech prováděných ohněm a vodou, což postupně vedlo k jejich zániku. Obecný zákaz ordálů pak přinesly konstituce Fridricha II. v roce 1231 . V českém království pak pražská synoda duchovenstva, svolaná z popudu Karla IV. tehdy ještě biskupem Arnoštem z Pardubic, zakázala kněžím účast na ordálech. ${ }^{6}$

V počátcích středověké státnosti církev také v mnoha směrech nahrazovala státní moc a ukládala církevní tresty za provinění, které světské orgány zatím netrestaly. Vedle obvyklých postihů, jako zákazu účasti na bohoslužbách či vystavení před vchodem do chrámu, to bylo i vyhnanství, jak to uvádí zmíněná Dekreta Břetislavova, zřejmě podle vzoru západních církevních předpisů. ${ }^{7}$

Vliv církve na vývoj a charakter procesu však nekončil ani zaváděním nové formy trestního procesu inkvizičního, spíše naopak. Popudem k zavádění procesu inkvizičního, ve kterém již neplatila zásada „kde není žalobce, není soudce“, kde naopak již samo podezření ze spáchání deliktu bylo důvodem k zahájení trestního stíhání a uplatňovala se presumpce viny, se stalo pronásledování kacířství, jak byla označována vědomá úchylka od dogmat církví katolickou oficiálně zastávaných. Pachatel tohoto deliktu byl po odsouzení církevním soudem předán světské moci $\mathrm{k}$ potrestání bez prolévání krve, tj. $\mathrm{k}$ upálení zaživa. Bulou Inocence IV. z roku 1252 bylo povoleno užívat v kacířských procesech torturu, mučení, při výslechu obviněných či podezřelých, s tím, že se dopustili zločinu srovnatelného s velezradou, pro kterou již také v antickém Římě bylo dovoleno užívat při výslechu mučení. ${ }^{8}$

A tak se z procesu ztratilo přesvědčení, že to je Bůh, který při božím soudu ukáže pravdu a lež. Nyní to již byl sám obžalovaný, který musel na mučidlech prokázat svou nevinu. Na něm spočívala tíha důkazu neviny, a pokud se mu to nepodařilo, byl odsouzen. Tak započal ve středověku vývoj instituce inkvizičního (vyhledávacího) procesu užívaného nejen soudy církevními, ale i světskými postupně v celé Evropě a byl ukončen až v 19. století. 9

Bylo proto samozřejmé, že při sakrální podobě práva, při úloze, kterou měla církev ve středověké společnosti, byly jako těžké a často hrdelní zločiny považovány útoky, at' již

5 Srov. k tomu MALÝ, K. České právo v minulosti. Praha: Orac, 1995, s. 9-14, Počátky českého práva.

6 Tamtéž, s. 118. SATURNÍK, Th. Maiestas Carolina a její vliv na české právo obyčejové. Sborník věd právnich a státnich, 1918, roč. 18, s. 4-17.

7 Srov. MALÝ, Dějiny českého a československého práva do roku 1945, s. 142.

8 Srov. SCHILD, W. Die Folter als rechtliche Beweisverfahren. In: HINCKELDEY, Ch. (Hrsg.). Justiz in alter Zeit. Band IV. Rothenburg ob der Tauber: Kriminalmuseum Rothenburg, 1989, s. 241-287. MALÝ, K. Tři studie o trestním právu v českých zemích v 17. a v první polovinè 18. století. Praha: Univerzita Karlova v Praze, 2016, s. 70 a násl.

9 Tamtéž, s. 151. Autor uvádí data o ukončení užívání tortury v německých zemích - v Prusku 1740 při urážce majestátu, zemězradě a kvalifikované vraždě a v ostatních případech v roce 1754, v Bavorsku roku 1806, v Badensku 1831. V Habsburské monarchii bylo užívání tortury zastaveno již roku 1776. Z rozsáhlé literatury srov. zvl. FEHR, H. Zur Lehre vom Folterprozess. Zeitschrift der Savigny-Stiftung für Rechtsgeschichte, Germ. Abt., 1933, 53. 
fyzické, či verbální, na církev, na Boha a svaté. Tato delikvence byla stíhána jak orgány církevními, tak i světskými, kterým byl svěřován výkon trestu nad pachatelem.

Při rouhání šlo při tom leckdy o výroky pronášené z nevědomosti, zdánlivě běžné postěžování na životní situaci pachatele, ve kterých však soudní orgány nacházely urážku Boha a neváhaly ukládat tvrdé tresty, jako kupř. vytržení jazyka. U nás můžeme tuto podobu trestu nalézt v zákoníku městského práva z roku $1579,{ }^{10}$ ale je tu zrrejmě zachycena běžná praxe městských soudů i v době starší. Tu jsme však již v pramenné nouzi, nebot' zachované prameny českého středověkého práva mluví jen o právu šlechtickém, zemském, a delikty namířené proti církvi stíhané církví nezachycovaly. Není však pochyb, jak to ostatně dokládá i projekt zákoníku krále Karla IV. Maiestas Carolina, o stíhání a trestání kacířství, které ostatně právě ve 14. století bylo v Čechách hojně rozšířeno. ${ }^{11}$

Důsledkem husitství vznikla v Čechách složitá náboženská situace, dvojvěří, kdy vedle církve katolické byla dovolena podle basilejských kompaktát i církev kališnická a jen ostatní církve a vyznání byly považovány za kacířské a jejich vyznavači jako kacirri stíháni a trestáni. ${ }^{12}$ Avšak i jejich postih, pokud byli poddaní, byl komplikován v př́ípadech, kdy je jejich vrchnosti sdílející stejnou víru odmítly vydat k potrestání.

Ve městech, zejména královských, byl postih kacírư prováděn na základě práva kanonického a světské úřady tu plnily úlohu vykonavatele rozsudků soudů duchovních. Tato města byla také podrobena autoritě panovníka, který k postihu kacířství využíval i soud komorní. Rozhodování soudců bylo však často ovlivněno příslušností soudců k církvi.

Jednodušší byl postih deliktu rouhání, který byl považován za odsouzeníhodný bez rozdílu vyznání. Zmíněné ustanovení českého městského práva označuje pachatele deliktu za toho, kdo by „... Pánu Bohu, stvořiteli svému, zlořečil, aneb velebnosti božské utrhal...“, a připomíná původní trest Starého zákona ukamenování a nahrazuje ho trestem vytržení jazyka. ${ }^{13}$ Tento delikt měl oporu v kanonickém právu, v knize VI., která hovoří o církevních trestech. V tomto ohledu je zvláště významný kánon 1369, ve kterém se praví, že „,kdo na veřejném představení nebo shromáždění nebo veřejným písemným projevem nebo jinak ... pronáší rouhání nebo těžce poruší dobré mravy nebo uráží náboženství nebo církev nebo vzbuzuje vůči ní nenávist nebo pohrdání bude postižen spravedlivým trestem. “ Také v dalších kánonech je chráněna církev - v kánonu č. 374 je stíhán trestem člen sdružení, které brojí proti církvi, v č. 376 se stíhá zneuctění movitých nebo nemovitých posvátných věcí, kánon č. 1364 exkomunikuje bludaře, č. 1368 stíhá křivou přísahu. ${ }^{14}$

Dalším deliktem namířeným proti Bohu bylo čarodějnictví, za které podle středověkých koncepcí, které přežily až do novověku, leckde v Evropě až do konce 18. století, bylo považováno dorozumění, smlouva s d'áblem.

Na samém konci středověku, roku 1487, sepsali němečtí dominikáni Jakub Sprenger a Heinrich Institoris „odbornou“ př́ručku ke stíhání čarodějnic pod názvem Malleus Maleficarum, neboli Kladivo na čarodějnice. Skutečně, za potenciální pachatelky čarodějnictví

\footnotetext{
10 Srov. MALÝ, K. Trestní právo v Čechách v 15.-16. století. Praha: Univerzita Karlova, 1979, s. 44.

11 Tamtéž, s. 36-44.

12 Srov. MALÝ, Dějiny českého a československého práva do roku 1945, s. 50.

13 Srov. MALÝ, Tři studie o trestním právu v českých zemích v 17. a první polovině 18. století, s. 43.

14 Srov. Codex Iuris Canonici, L.P. 1983, překlad do češtiny. Z latiny přeložil prof. JUDr. ThDr. M. Zedníček. Praha: Zvon, české katolické nakladatelství, spol. s r. o., 1993.
} 
byly považovány především ženy, o kterých se předpokládalo, že se nejenom dopouští odpadnutí od víry, ale že se s d'áblem spojují i tělesně.

Rozhodnutím papeže Řehoře XV. z roku 1623 měly být osoby, o nichž se předpokládalo, že uzavřely smlouvu s d'áblem, předány $\mathrm{k}$ potrestání světské moci. Zejména v německých zemích došlo v 16. století k masovým čarodějnickým procesům, které vedly k popravám tisíců obviněných, většinou žen. ${ }^{15}$ Tresty za čarodějnictví byly neobyčejně kruté - upálení zaživa či zahrabání zaživa a probodení srdce zahroceným kůlem.

V našich zemích byla intenzita stíhání čarodějnictví ve srovnání se sousedním Německem relativně nízká, spíše než o projevy temné magie šlo v těchto procesech o delikty kriminální povahy jako travičství, potraty apod. Na mírné tresty zřejmě působil vliv náboženské tolerance a nalézáme dokonce i zprošt’ující rozsudky, kdy soudci mluví o pouhých pověrách. ${ }^{16}$ V českých zemích také neplatil zákoník Karla V. Constitutio Criminalis Carolina $\mathrm{z}$ roku 1532, který zavedl v německé ř́ŕši inkviziční proces a jehož podpůrnou platnost zavedl u nás až na počátku 18. století zákoník Josefa I. ${ }^{17}$

\section{II.}

Porážkou českého stavovského povstání, nástupem absolutismu a novým zákoníkem zemského práva, Obnoveným zř́zzením zemským z roku 1627, ${ }^{18}$ se změnila nejen ústava českého království a o rok později vydaným zemským zřizením i moravského markrabství, ale i postavení katolické církve, která se stala v těchto zemích jedinou povolenou církví a náboženství katolické výlučným náboženským vyznáním, a to až do vydání tolerančního patentu Josefa II. v roce 1781. Judaismus byl trpěn, počet osob židovského vyznání regulován.

S nástupem pobělohorské rekatolizace bychom mohli očekávat, že Obnovené zřízení bude věnovat zvláštní pozornost trestně právní ochraně církve, avšak to se spokojilo se starou, ještě stavovskou právní úpravou, tak jak byla obsažena v zákoníku městských práv, který měl být používán v případech, kdy v novém zákoníku chyběla potřebná právní úprava.

K novému zakotvení právních předpisů o rouhání tak došlo až na počátku 18. století v již zmíněném zákoníku Josefa I., v tzv. Josefině, vydaném v roce 1707.19

Stejně jako ostatní trestněprávní předpisy týkající se ochrany víry a církve, i úprava stíhání rouhání je tu podstatně rozšířena a upravena, i když i zde nalézáme zbytky staré stavovské právní úpravy.

15 Čarodějnickým procesům byla v právněhistorické literatuře, zejména německé, věnována mimořádná pozornost, v poslední době pak zejména jejich sociálním prŕíčnám a důsledkům. Za mnohé srov. KIMMERLE, G. Hexendämmerung. Tübingen: Konkursbuch Verlag, 1980, a SCHORMANN, G. Hexenprozesse in Deutschland. Göttingen: Vandenhoeck und Ruprecht, 1981. Postih tohoto crimen magie nalezneme již v Saském a Švábském zrcadle. Roku 1484 se proti této delikvenci vyslovil v bule Summis desiderantes affectibus papež Innocenc VIII. Základní příručkou k boji proti čarodějnictví se stala již zmiňovaná kniha Malleus maleficarum. Pro německou říši se stal zákonným podkladem postihu čarodějnictví trestní zákoník císaře Karla V. z roku 1532 Constitutio Criminalis Carolina, který ovlivnil zákonodárství v řadě evropských zemí i v druhé polovině 18. a na počátku 19. století.

16 Srov. MALÝ, Trestni právo v Čechách v 15.-16. století, s. 44-46.

17 Srov. MALÝ, Tři studie o trestním právu v českých zemích v 17. a první polovině 18. století, s. 119.

18 Srov. tamtéž, s. 77-112, Obnovené zrrízení zemské a nové pojetí trestního práva.

19 Srov. tamtéž, s. 119. 
O deliktu rouhání se v Josefině mluví v art. V., $§ 16$, kde je stanoveno, že soudce v případě rouhání proti Bohu nebo jeho vyobrazení musí vyslechnouti dva svědky, nebo kdyby to nebylo možné „... toliko jednoho viry hodného svědka s předcházející př́sahou slyšeti..." Podoba této př́isahy je obsažena v tomtéž článku v $§ 7 .{ }^{20}$

Vlastní postih útoků proti Bohu a církvi je obsažen v art. XIX., v § 1 o rouhání, v $§ 2$ o kacíršství, v $\$ 3$ o čarodějnictví, v $§ 4$ o křivé prŕísaze a v $\$ 5$ o odpadnutí od víry. ${ }^{21}$

Za rouhání, které je prohlášeno mezi zločiny za „... nejhorší a nejohavnější ... je považováno ... zlořečení, v kterémž skrze svaté svátosti, rány, kř̌žž a umučení Spasitele zoumyslně a z pouhé zlosti zlořečení se zavírá..." Toto rouhání je podle textu zákona namíreno proti Bohu, Matce boží a svatým a děje se „... slovy, neb skutkem ... kdež někdo Bohu neb jeho svatým nětco přičítá, připisuje neb odnímá, což jemu a jim přináleží a přísluší, neb nepřináleží a nepř́ísluší..." 22

Za rouhání spáchané verbálně je uložen tradiční trest vytržení jazyka, za rouhání spáchané skutkem pak utětí ruky. $\mathrm{V}$ obou př́ípadech pak následuje ještě trest spálení těla pachatele. Jen v případě, že by soudci shledali, že rouhání se nestalo ,... v nejvyšším stupni...", což ovšem zákon nijak nespecifikuje, nastoupilo místo popravy upálením ,pouhé“ stětí pachatele.

Text Josefiny v této souvislosti označuje toto mírnější jednání za rouhání prvého stupně a mluví o jednání, kdy pachatel svého jednání lituje, rouhání pronesl v nesrozumitelné cizí řeči nebo posvátný předmět, který urazil, neznal. V takovém případě není mu uložen uvedený př́isný trest tělesný a hrdelní a způsob potrestání se ponechává na volném uvážení soudce. Tím byl delikt rouhání zařazen na první místo mezi nejtěžší hrdelní zločiny. ${ }^{23}$

Kacírství bylo v tomtéž artikulu v $§ 2$ prohlášeno za zločin náležející ,... ku právu duchovnímu“, ale, kdyby mělo za následek „... rušení veřejného pokoje, a tudy bud’ povstalé neb povstáti mohoucí bouřky ... je pokládáno za protistátní delikt crimine contra statum a má být trestáno na hrdle či jinou tělesnou pokutou“. ${ }^{24}$

Dalším deliktem uvedeným v $§ 3$ je kouzelnictví a čarodějnictví, které je tu podrobně popsáno, včetně návodu na otázky, které má vyšetřovatel obžalovaným klást. ${ }^{25}$

Trest za tento delikt je odstupňován podle druhu jednání pachatele. Upálením je trestán ten, kdo spáchá „... skutečné čarodějnictví, které by ... bud’ patrným, neb tajným závazkem a ... s zlým duchem smlouvou se stalo...“. I tu bylo možné zmírnění trestu, pokud byl pachatel nízkého věku či snížené př́íčetnosti a následoval ,jen“ trest stětí. Zákon pak připouští dokonce jen trest mrskání metlami a vypovězení nebo u poddaných dva či tři roky veřejných prací v př́́padech, kdy nebyla zjištěna velká škoda, a pachatel složil přísahu a veřejně se omluvil. Takto byli postiženi i ti, kteří využívali rady a pomoc čarodějníků.

20 Srov. KOUPIL, O. - KOUPILOVÁ, M. - MALÝ K. a kol. Nové právo útrpné a hrdelni pro království České, markrabství Moravské a knižectvi Slezské Josefa I: První kritická edice české verze zákoniku. Prameny $k$ dějinám trestního práva v českých zemích v obdobi absolutismu. Praha: Karolinum, 2018, S. 285 .

21 Tamtéž, s. 310.

22 Tamtéž.

23 Tamtéž, s. 310.

24 Tamtéž, s. 310-311.

25 Tamtéž. 
Naproti tomu pachateli přitěžovalo, když při kouzlech byly využíány posvátné věci nebo svátosti.

Dalším z útoků na Boha a církev je křivá přísaha, jejíž trestání je upraveno v art. XIX., $\S 4 .^{26}$ Je popsáno jako jednání „... když velebnost božská v nepravdivé věci neb případnosti za svědka se bere“. Jinými slovy, je tu Bůh uražen lživým odvoláním, lživou přísahou. Trestem je poprava mečem, která může být zostřena, pokud měla křivá přísaha škodlivé následky, jako ku př́ikladu škodu na majetku. Stejné následky mělo i porušení přísahy v případě, že by se vypovězený „... proti přísežnému zápisu...“ vrátil do země.

Posledním deliktem uváděným v této souvislosti je v $§ 5$ odpadnutí od víry. ${ }^{27}$ Aniž by toto jednání bylo blíže specifikováno, je prohlášeno za stejné jako kacírsství s tím, že „... napodobně se pokračuje jako v kacírsstvu“, tj. trestní řízení i samotný trest.

Tato neobyčejně přísná úprava trestněprávní ochrany církve je v Josefině zaváděna pro všechny země České koruny a stala se pak vzorem pro trestní zákoník Marie Terezie.

\section{III.}

Tento zákoník vydaný po názvem Constitutio Criminalis Theresiana v roce 1768 sjednotil trestní předpisy i trestní proces v celém soustátí vyjma Uherského království a ukončil tak v duchu centralizačních reforem samostatný vývoj trestního práva v českých zemích. ${ }^{28}$ Úprava trestního stíhání útoků proti církvi, tak, jak jsme ji nalezli v Josefině, se v Tereziáně podstatně rozšířila. Článek padesátý šestý „O rouhání, neboližto zlolajičnosti proti Bohu“ je tu podán na čtyřech stranách velkého formátu a ve 12 paragrafech, které postupně charakterizují zločin rouhání - „Jak a kterak zlolajičnost proti Bohu se páchá“ -, za jakých podmínek a „,v jakém stupni zlolajičnosti“ může rozhodnout soudce podle zdravého rozumu, stanoví že „sprosté klení a přísahání“, nebo neohlášení tohoto zločinu není hrdelním deliktem, zavazuje vrchnostenské úřrady k pronásledování této delikvence, uvádí důvody k zahájení vyšetřování a k mučení, dává návod, jaké otázky mají být delikventům dávány, určuje tresty, uvádí okolnosti stěžující a polehčující a možnost kvalifikovat rouhání i jako kacírství. ${ }^{29}$

Rouhání je tu rozlišeno na tři stupně - v nejvyšším se předpokládá útok proti Bohu nebo Nejsvětější Trojici, a to jak slovy, tak fyzickým činem, tj. „když Bohu něco přičítá, co nepř́ísluší aneb něco ujímá, co jemu náleží“.

Ve druhém stupni je uváděna jako předmět útoku „Rodička Boží, neb jiný svatý ... Crucifix aneb jiný svatý obrazy vědomě a zoumyslně zláme, roztluče, aneb jinak zlosynně znectí..." Za třetí a nejméně závažný způsob rouhání se považuje klení a pasivní vyslechnutí rouhání. Určení, o jaký stupeň rouhání se v daném př́ípadě jedná, je ponecháno „větším dílem na zdravém uvážení soudce“.

Mezi šesti důvody, pro které má být zahájeno stíhání pachatele, je na prvém místě uvedena „,... veřejná pověst...“, ,,bezbožnost“", „pohoršlivý život“, opilství, hráčství, posmívání se pobožnosti, neúčast na bohoslužbách, špatné chování čeledi a dětí.

26 Tamtéž, s. 311-312.

27 Tamtéž, s. 312.

28 Ke vzniku a podobě tereziánského zákoníku trestního práva srov. MALÝ K. Poznámky k obecné části zákoníku Marie Terezie Constitutio Criminalis Theresiana. Právněhistorické studie, 2017, roč. 47, č. 1, s. 44-61.

29 Tamtéž, s. 50-51. 
Zákon také stanoví jako důvod pro vzetí do vazby přistižení při páchání rouhání a k uložení útrpného výslechu stačí svědectví jednoho hodnověrného svědka anebo při domovní prohlídce nález poškozených vyobrazení nebo vlastní rukou obviněného zapsané písemné rouhání.

Tresty mimořádně kruté se rozlišují podle závažnosti provinění - v prvém stupni je to tradiční vytržení jazyka nebo utětí ruky a upálení zaživa s možností zostření trháním řemenů, trháním rozžhavenými kleštěmi a vláčením na popraviště. Při tzv. druhém stupni čekalo pachatele místo upálení ,jen“ stětí, ale nevyhnul se vytržení jazyka či utětí ruky. Ve třetím stupni za pouhé klení je pachatel svěřen k potrestání své vrchnosti.

Za rouhání se výslovně v $§ 12$ nepovažují projevy odlišných náboženských názorů př́islušníků jiných „bludných“ vyznání a jejich př́ípadné trestání se má dít podle „zemských zákonư“ o kacíŕích. Kaciřsství tedy není považováno za rouhání. ${ }^{30}$

Př́ínost postihu a důkladnost právní úpravy nepotřebuje zvláštní komentář. Je to ostatně, stejně jako řada dalších ustanovení, posledním projevem středověkého pojetí práva, a to v době, která se již hlásí k novému osvícenskému myšlení. ${ }^{31}$

Také dalši článek - padesátý sedmý - je věnován ochraně církve, resp. křest’anské víry. Je nazván O odpadnutí od křest’anské víry. Hned v úvodu stručného ustanovení se konstatuje, že není namířen proti kacířům, kteří když přijali katolickou víru, od ní opět odpadli, stejně jako proti duchovním, kteří po vysvěcení svi̊j stav opouštějí, nebo proti mnichům, kteří zběhli z kláštera. Za pachatele jsou považováni křest’ané, kteří „... od křest’anstva odpadají, a naproti tomu židovskou, mahometánskou, aneb pohanskou víru přijímají“. Nemluví se tu o bezvěrectví a nerozlišují se jednotlivé druhy křest’anské víry. Trestem je propadnutí jmění a stětí mečem s tím, že se ponechává na uvážení soudce zpřísnění nebo zmírnění trestu. ${ }^{32}$

Článek padesátý osmý je pak věnován postihu čarodějnictví, resp., jak zní název článku „kauzedlnictví, čarodějnictví, hadačtví, a těm podobným“.

Dostáváme se tedy k oné pověstné části tereziánského zákoníku, která jej poznamenala svou zaostalostí, a ve své době již spíše vyvolávala posměch. ${ }^{33}$ Ostatně sama císařovna si toho byla vědoma, jak ještě ukážeme, a její kritický pohled na tento delikt se v textu tohoto ustanovení také náležitě uplatnil.

Pro církev bylo čarodějnictví útokem na víru, na Boha, nebot' podstata deliktu podle zákonodárců, kteř́ se tu řídili oním pověstným Kladivem na čarodějnice, spočívala v tom, že pachatel se spojil s d'áblem, o jehož existenci neměli pochyb. V úvodu § 1 se to výslovně stanoví slovy, že tento delikt se spáchá tím, že „,.. když kdo s d’áblem zacházení,

30 Srov. Constitutio Criminalis Theresiana aneb řimské císařské v Uhř́ch a Čechách etc. etc. královské apoštolské milosti Marie Terezie arcikněžny rakouské, etc. etc. Hrdelni právni řád. V Vídni, vytištěný u Jana Tomáše urozeného z Trattnern, císařsko královskýho impressora 1769, čl. 56, § 1-12, s. 162-165, dále jen CCT.

31 Srov. MALÝ, Poznámky k obecné části zákoníku Marie Terezie Constitutio Criminalis Theresiana, s. 59-60. ŠVECOVÁ, A. Beccariovský obrat ponímania trestného činu v konfrontacii s trestnoprávnou úpravou v Uhersku a Habsburskej ríši v 18. a na začátku 19. storočia. Právněhistorické studie, 2017, roč. 47 , č. 1 , s. $62-74$.

32 Srov. CCT, Článek padesátý sedmý: O odpadnutí od křestanské víry, s. 166.

33 Srov. CCT, Článek padesátý osmý: O kouzedlnictví, čarodějnictví, hadačství, a těm podobných, s. 166-173, srov. zvl. MALÝ, Poznámky k obecné části zákoníku Marie Terezie Constitutio Criminalis Theresiana, s. 45, vyjádření kancléře Kaunitze. 
společnost míti, s ním ve vejslovný, aneb tajný závazek vejíti, a s takovou zjednanou pomocí d’ábla rozličné nad lidskou moc, a sílu s vztahující věci, bez, aneb s cizím škozením tropiti, a tak značené nešlechetnosti provozovati sobě osobuje“. O jaké osoby, které tu připadají v úvahu, se jedná, je tu dále stanoveno.

Do tohoto textu však vstupuje náhle kritický proslov či úvaha, jejíž autorkou či iniciátorkou byla zřejmě císařovna s úmyslem zpochybnit samu podstatu definice čarodějnictví. Císařovna tu čelí kritice členů svého kabinetu a volí kompromisní cestu - jednak zpochybňuje samotný pojem čarodějnictví jako projev ,... náchylnosti prostého lidu k pověrečným věcem...“, mluví o tom, že zdrojem těchto představ je „hloupost a nevědomosti“", že ,,.. bez činění rozdílu mezi pravdou a klamem při obecném lidu lehkověrnost povstala ... všecky takové př́íhody, které hned lehce pochopiti nemůže ... jenž zcela přirozené jsou, jako povětří, aneb bouřka, pád dobytčí, nemoci těla etc. d'áblu a jeho nástrojům, totiž čarodějníkům a kouzlám připisovati.“ Uvádí také, že tyto představy o čarodějnictví jsou vštěpovány „,... dětem téměř v kolíbce strašlivými povídkami a pohádkami““.34

Současně pak s odvoláním na povinnost „... čest Boží podle vší síly ... v náležitým stavu zachovati a ... všecko co jí k újmě směřuje, obzvláštně ale předsebrání čarodějných jednání vyhladiti“. Tak tu dochází k jakémusi kompromisu - na jedné straně žádné srozumění s d'áblem neexistuje, ale protože je nezbytné církev chránit, ponecháme přece jen její právní ochranu před čarodějnictvím.

Text zákona pak dává podrobný návod soudům, co mají při obvinění z čarodějnictví zkoumat a vyšetřovat, a to ve čtyřech zde uvedených prŕpadech. V prvém jde jen o podvodné vydávání se za čarodějníka, v druhém jde o duševně nemocné, ve třetím pak jde o skutečnou žádost obviněného o d'áblovu pomoc, avšak neúčinnou, a konečně v posledním případě se pak připouští možnost, že ,... taková nešlechetnost, která podle běhu přirozenosti od člověka samého od sebe v skutek uvedená býti nemohla, s zjednanou pomocí a přispěním d'ábla $\mathrm{z}$ dopuštění božího se stala..."A tak se nakonec přece jen připouští reálnost čarodějnictví.

Císařovna však současně $\mathrm{v} \S 6$ zapovídá jakékoliv dosavadní soudní praktiky při vyšetřování, jako kupřr. hledání „d’ábelského znamení“ etc. Nakonec je tu v § 7 uzákoněna důležitá pojistka - císařovna si vyhrazuje schválení každého rozsudku nad čarodějníkem před jeho provedením. Spisy od hrdelního soudu mají být před vynesením rozsudku předány vrchnímu právu a ten je pak se svým stanoviskem předá panovnici. Ta si pak pochvaluje, že za „,... jejího panování dosaváde žádný pravý čarodějník, kouzelník nebo kouzedlnice odestřené nebyly, nýbrž takový spory vždy na zlosynný podvod, aneb hloupost a pošetilost vyšetřovance, aneb na jiný zloskutek vypadly, a s citelným potrestáním podvodníka neb sic zločince, aneb s zamčením pošetilého se skončily“.35

Tak další text $\S 8-12$ o právních předpokladech pro zahájení vyšetřování a použití útrpného výslechu již nemají praktický význam a jsou jen názorným dokladem starších praktik, odvozených od Kladiva na čarodějnice. ${ }^{36}$

Tečku za čarodějnickými procesy obsahuje $§ 13$, ve kterém se v př́ípadě výskytu různých pověr stanoví povinnost lékařského vyšetření osob zastávajících takové bludy, v případě

\footnotetext{
34 CCT, $\S 3$, s. 167.

35 CCT, $\S 7$, s. 169.

36 CCT, § 7-12, s. 169-171.
} 
podvodu potrestání pachatele, v př́ípadě duševní choroby předání „... do bláznivého domu aneb nemocnice“. A kdyby přece jen u podř́zených soudů byla pochybnost, zda přece jen nejde o spolčení s d’áblem, mají to svěřit panovnici ke konečnému rozhodnutí. ${ }^{37}$

Ačkoliv tak panovnice zabránila honu na čarodějnice, přece jen zákonná úprava deliktu čarodějnictví vtiskla jejímu zákoníku pečet’ posledního symbolu středověké justice.

$\mathrm{Z}$ dalších deliktů, namířených proti církvi je z Josefiny do tereziánské kodifikace převzato ustanovení o křivé přísaze v článku 59. nazvaném „O klamném přísahání, a křivopřísežnictví“. 38 Podstata provinění je popsána jako jednání, když se „vědomě, a podvodným způsobem Bůh za svědka k nepravdivé věci se uvádí...“ a proto ,... jest spůsob zlolajičnosti proti Bohu..." Za pachatele je považován jak ten, kdo úmyslně složí křivou př́sahu, tak ten, kdo ji složí v dobré víře, že jí dostojí, ale později ji poruší.

Trestem za úmyslné křivopřísežnictví je poprava mečem s možností zostření vytržením jazyka a usečením prstů, kterými pachatel přísahal. Jako důvod pro zpřísnění trestu je uveden škodlivý následek - např. ,... klamné svědectví někoho z nějakého zloskutku ... na který zostřený hrdelní trest ... vyměřen jest..."

Př́ípadné polehčující okolnosti jsou ponechány na uvážení soudce a obviněný, pokud není př́islušný do země, má být vypovězen ze všech „dědičných“ zemí. Je tu také zakotveno právo na náhradu škody způsobené křivou přísahou a podrobně stanoveny $\mathrm{v} \S 4$ okolnosti přitěžující a polehčující. Intenzitou trestního postihu se ani tento druh útoku proti církvi neliší od starší právní úpravy.

\section{IV.}

Základní změnu ve vývoji trestního práva v našich zemích přineslo panování Josefa II., reformy a zákony, které jsou s jeho jménem spojeny. Tyto změny se pochopitelně také projevily v trestněprávní ochraně církví.

V novém zákoníku trestního práva - Zákonu o zločinech a jich trestání z roku $1789^{39}$ se projevily vlivy současné osvícenské ideologie, zvláště C. Beccaria a jeho díla Dei delitti e delle pene, a to jak v systému trestního práva hmotného, tak i procesního. ${ }^{40} \mathrm{Již} \mathrm{v} \mathrm{počát-}$ cích Josefova panování byl zastaven výkon trestu smrti císařskými rezolucemi z roku 1781 a 1783 a jeho zákoníkem byl pak zrušen trest smrti, resp. ponechán jen pro případ stanného práva. Stalo se tak zejména pod vlivem prof. Keesse. ${ }^{41}$ Další tereziánský relikt středověku, tortura, byl již odstraněn od roku 1776 jako forma výslechu. Podle Josefa II. byla účelem trestu převýchova pachatele, nikoliv pomsta; uplatňuje zásadu rovnosti před zákonem a soudem, zavádí zásadu nullum crimen sine lege, nulla poena sine lege a podrobuje tak soudce autoritě zákona. Současně ale byly zavedeny kruté tresty, které nahrazovaly trest smrti - tahání lodí na Dunaji, zrušené až roku 1795, brutální formy vězení s ukováním a tělesnými tresty, které vedly k rychlé smrti vězňů. Je zachováno vypalování potupných

\footnotetext{
37 CCT, § 16, s. 173.

38 CCT. Článek padesátý devátý: O klamném přisahání a křivopřisežnictví, § 1-4, s. 173-174.

39 Srov. Allgemeines Gesetz über Verbrechen und deselben Bestrafung, Wien, gedruckt bei Johann Edlen von Trattnern, k.k. Hofdruckern und Buchhändlern, 1787.

40 Srov. BECCARIA, C. Dei delitti e delle pene. [Livorno: Marco Coltellini], 1764. K významu díla srov. PRUŠÁK, J. Rakouské právo trestní. Praha: Spolek českých právníků „Všehrd“, 1912, s. 7-8.

41 Srov. PRUŠÁK, op. cit., s. 189.
} 
cejchů, tresty bití, vystavování na pranýř, veřejné oznamování odsouzení, tresty na mrtvém, je ponechán proces inkviziční. ${ }^{42}$

Josef II. se tak sice jeví jako osvícenský panovník, s jehož jménem je spojena řada reforem, které přibližují země habsburské monarchie modernímu světu, ale nebyl v žádném př́ípadě humánním reformátorem. Mezi jeho významné reformy jistě patří zrušení nevolnictví, toleranční patent, zásah do církevních svátků, rušení klášterů, zásahy do majetkových práv církve a snaha podrobit katolickou církev autoritě státu, reforma trestního práva hmotného a procesního a vypracování prvého dílu občanského zákoníku. ${ }^{43}$

Současně však ho ovládal necitlivý racionalismus, etatismus, který se snažil podrobit občana autoritě státu, považoval se za prvního úředníka státu a pro své úředníky vypracoval prohlášení o jejich poslušnosti a oddanosti státu, zavedl jako jedinou státní řeč němčinu. ${ }^{44}$

Jeho zákoník již nezná delikt čarodějnictví, tedy jeden z klíčových deliktů tereziánské kodifikace. Z ostatních deliktů, které tvořily systém trestní ochrany církve, zůstalo rouhání, rušení náboženských obřadů církví státem uznaných nebo povolených a vybízení k odpadnutí od křest'anské víry. Delikt křivé přísahy ztratil svou duchovní podobu a stal se součástí ochrany práv majetkových a osobnostních. Sebevražda zůstala jako trestný čin namířený proti Bohu a státu.

Delikty proti církvi nalézáme $\mathrm{v}$ páté kapitole druhé části zákona o přestupcích v § 61-68. ${ }^{45}$ Za přestupek je v $\S 62$ prohlášeno rušení náboženských obřadů církví panujících nebo státem uznaných, stejně jako veřejné zneuctění předmětů sloužících bohoslužbě. Trestem je podle $\S 63$ prísné vězení s posty a v př́padě, že by jednání mělo za následek veřejné pohoršení, může být trest zpřísněn výpraskem.

Za přestupek je v § 64 prohlášeno jednání, které má za cíl odpadnutí od křest'anské víry, opuštění všech náboženství „... die das Evangelium läugnet, zu verletten“. 46 Stejně je postiženo v $\S 65$ hlásání falešného učení nebo bezvěrectví. Trestem je podle $\S 66 \mathrm{v}$ prvém př́ípadě vystavení na pranýři a přísný dočasný trest vězení, v druhém případě pak dočasný trest vězení.

Sebevražda byla dále považována za kriminální zločin a zařazena do čtvrté kapitoly prvního dílu zákoníku na straně 38-52 nazvané „Von Verbrechen, die auf das menschliche Leben und körperliche Sicherheit unmittelbare Beziehung haben“. Definice sebevraždy je podána $\mathrm{v} \S 123 \mathrm{~s}$ tím, že pokud $\mathrm{k}$ činu nevedly zdravotní důvody, má být tělu zakázán pohřeb v řádném hrobě a má být jen zahrabán beze všech obřadů. Jméno sebevraha má být přibito na šibenici (\$ 124). O povaze činu jako namířeného proti Bohu se mluví až v závěru $\S 125$ věnovanému pokusu sebevraždy, který stanoví pro neúspěšného pachatele vězení na neurčenou dobu (auf unbestimmte Zeit) s tím, že bude propuštěn, až bude zřejmé jeho polepšení, pokud jde o povinnost ,gegen Gott und Staat“. 47

42 Tamtéž, s. 190.

43 Srov. MALÝ, K. Problém kontinuity a diskontinuity v trestním zákonodárství konce 18. a počátku 19. století. In: ŽÁK KRZYŽANKOVÁ, K. a kol. Právo jako multidimenzionálni fenomén. Pocta Aleši Gerlochovi k 65. narozeninám. Plzeň: Aleš Čeněk, 2020, s. 696-702. MALÝ, Dějiny českého a československého práva do roku 1945, s. 193-194.

44 Srov. tamtéž, s. 175-178.

45 Allgemeines Gesetz über Verbrechen und derselben Bestrafung, s. 109-112.

46 Tamtéž, s. 110.

47 Tamtéž, s. 52. 
Soustava trestů daná josefinským procesním řádem z roku 1790 byla poměrně složitá. Za přestupky v uvedených deliktech hrozil pachateli za jednání uvedené v druhé části zákona o přstupcích „Von politischen Verbrechen und politischen Strafen“ v $§ 62$ trest odnětí svobody na 5-8 let, v př́ipadě druhém trest v délce od 1 měsíce do 5 let. Trest půstem spočíval v tom, že vězeň dostával jeden den v týdnu jen vodu a chléb.

Tak se z kriminálních a hrdelních zločinů staly přestupky, souzené správními vrchnostmi. Trestněprávní ochrana církve tak dostala jinou podobu, jinou intenzitu, která pak ovlivnila další vývoj.

V.

Nový trestní zákoník vyšel pod názvem Kniha práv nad přečiněními hrdelními a těžkými řádu městského, (totiž policie) přestupky, vydaná česky v roce 1804, autentické německé vydání pak v roce $1803 .{ }^{48}$ Zákoník se skládal ze dvou dílů a každý díl ze dvou částí. Prvý díl v prvé části pojednával o zločinech (přečiněních) a jejich trestech (§1-210), druhá část obsahovala předpisy o trestním řízení (\$ 211-557), druhý díl v prvé části obsahoval předpisy „o těžkých řádu městského (policie) přestupcích a jich trestech“ (§ 1-275) a druhá část obsahovala předpisy o trestním řízení (§ 276-459).

Zákoník měl zásadní význam pro další vývoj rakouského trestního práva, byl sice v roce 1852 nahrazen novým zákoníkem, ale ten byl spíše jen novelou a přebíral, leckdy doslova, právní předpisy původní, a tak se stal základem rakouského práva nejen pro 19 ., ale i 20. století. Byl rakouskou právní vědou vysoce ceněn a označován za dílo na svoji dobu skutečně mistrovské (Prof. Josef Prušák). ${ }^{49}$

Vedle nesporných předností, kterými byl především jeho dokonalý systém, zmírnění trestů oproti Josefinskému zákoníku, omezení trestu jen na pachatele a vyloučení postihu jeho př́buzných, nová úprava promlčení, zrušení trestu propadnutí majetku, přesnější úprava přestupků a podrobení soudců autoritě zákona, měl nový trestní zákoník také zjevné nedostatky, např. při úpravě výkonu trestu odnětí svobody a ukládání tělesných trestů. Jsou na něm patrné vlivy tehdejší společenské a politické situace, napoleonských válek a hrozby revoluce a nastolení policejního státu.

Nová právní úprava se dotkla i předpisů, které vytvářely trestní ochranu církve a víry. V hlavě čtrnácté pod titulem „O rušení náboženstvi““ se v § 107-10950 sice přejímá konstrukce Josefinského zákoníku, ale z pouhého přestupku se stává zločin. V § 107 se uvádějí čtyři druhy rušení náboženství: kdo a) „rouhání řečmi, písmi, a spisy, neb skutky Bohu se rouhá“, b) rušení „,provozováni'“ náboženství, „neuctivé a potupné nakládání s věcmi k službě Boží odkázanými, aneb sice řečmi, písmi, a spisy tupení náboženství veřejně na sobě znáti dává““, c) vybízení křest’ana k odpadnutí od křest’anské víry, d) rozšiřování nevěry a bludu.

V $§ 109$ se trestá rušení náboženství žalářem od šesti měsíců do jednoho roku, v případě přitěžujících okolností uvedených v $§ 108$, tj. pokud rušení náboženství způsobilo veřejné pohoršení nebo ohrozilo veřejnou bezpečnost, pak byl ukládán trest od jednoho do pěti let, při větším nebezpečí až deset let. To je nepochybně zpřísnění původních trestů i kvalifikace

Srov. Kniha práv nad prečiněními hrdelními a těžkými řádu městského (totiž policie) prestupky. Ve Vídni u Jana Tomáše urozeného z Tratnnerův, cís. král. dvořského knihtlačitele a prodávatele, 1804.

49 PRUŠÁK, op. cit., s. 13.

50 Tamtéž, s. 61-62. 
jednání, jak byly obsaženy v Josefinském zákoníku. Toto zpř́ísnění nepochybně odpovídá významu, jaký je státní mocí přiznáván církvi a jejího významu v tehdejší společnosti.

Křivá př́ísaha - v zákoníku se mluví o falešném přísahání, podobně jako v zákoníku Josefinském - je zařazena mezi zločiny majetkové, trest za ni dle § 177-178 závisel jak na výši způsobené škody, tak i na tom, zda falešná přísaha byla složena před soudem. S trestem těžkého žaláře pak bylo spojeno vystavení na pranýři. Trest žaláře mohl podle přitěžujících okolností být bud' dvacetiletý, nebo doživotní.

Stejně tak do značné míry ztratil svůj duchovní rozměr nyní již jen přestupek pokusu sebevraždy zařazený do hlavy osmé „O těžkých řádu městského přestupcích proti bezpečnosti života“ v $\S 90$ : „Jestli kdo s předsevzetím života se zbaviti se poraní, neb urazí, ten pokudž od vyvedení sebevraždy vlastním pykáním upustil, před vrchnost povolán a za př́íčinou mrzkosti předsevzetí svého ... těžce napomenut býti má". ${ }^{51}$ Je tu tedy upuštěno od uložení vězení a podle ustanovení § 91 má být pachatel léčen či donucen „prostředky mravnými a fysickými ... k rozumu a poznání povinnosti své stvořiteli, vlasti a sobě samému..." A tak byla otevřena cesta k novému pojetí trestní ochrany církve, víry a náboženství.

\section{VI.}

Novou úpravu trestního práva bychom měli očekávat v souvislosti s revolučním rokem 1848, který, podobně jako téměř v celé Evropě, zasáhl i habsburské soustátí. Revoluce nepřinesla do právního řádu monarchie v tomto ohledu žádné zásadní změny a opatrné pokusy v březnové a Kroměřížské ústavě vyzněly do prázdna. Naopak, obavy z revolučního hnutí, silný policejní absolutismus, obavy z radikalismu revolučních sil vedly ke spolupráci státu s katolickou církví. Výsledkem pak byl konkordát z roku 1855 mezi rakouským státem a katolickou církví publikovaný papežem v bule Deus humanis auctor a vyhlášený císařským patentem z 5. 11. 1855 pro celou říši, čímž byly položeny základy k obnově moci katolické církve v habsburském mocnářství ${ }^{52} \mathrm{~V}$ Uhrách se nepodařilo konkordát prosadit a jakákoliv možnost zanikla judexkuriální konferencí v roce 1861. Tento vývoj postavení církve se samozřejmě projevil i v její ochraně, při trestněprávní úpravě postihu rouhání a urážky církve.

Trestní zákon o zločinech, přečinech a přestupcích ze dne 27. 5. 1852 číslo 117 říšského zákoníku převzal v podstatě právní úpravu z roku 1803, a to v hlavě 13, § 122-124 „O rušení náboženstvi““, a prohlásil rušení náboženství za zločin.

Stejně jako v trestním zákoníku z r. 1803 i zde je převzat v § 122 systém čtyř druhů jednání, která měla za následek rušení náboženství - a) rouhání se Bohu „řečmi, činy, v tiskových dílech nebo rozšiřovaných spisech...", b) rušení výkonu, provozování, náboženství státem uznané nebo zlé nakládání s nářadím zasvěceným bohoslužbě nebo projevy veřejného opovržení vůči náboženství ,کřčmi, v tiskových dílech nebo rozšiřovaných spisech“, c) svádění k odpadnutí od křest’anské víry, d) rozšiřování nevěrectví. Stejný, doslova, zůstal i trest - podle $\S 123$ je to v př́padě, že bylo „... rušením náboženství dáno veřejné pohoršení, nebo byl-li kdo sveden nebo bylo-li s tím spojeno obecné nebezpečí...“ těžký žalář od jednoho do pěti let s možností zpř́ísnění trestu až na deset let, pokud byla

51 Tamtéž, s. 47-48.

52 Srov. MALÝ, Dějiny českého a československého práva do roku 1945, s. 268-270. 
shledána „... velká zlomyslnost nebo nebezpečí...“ Ovšem v případě, že nebyly shledány tyto přitěžující okolnosti, byl trest stanoven podle vzoru zákona z r. 1803 jen na šest měsíců nebo jeden rok.

Základní vliv na úpravu vztahu církví a občanské společnosti přinesla poslední rakouská ústava prosincová, vydaná jako „Základní zákon státní, daný dne 21. prosince 1867 “53 Skládala se ze zákonů č. 141-145 ř. z. Ústava zakotvila řadu občanských práv - rovnost před zákonem, rovný přístup ke státním úřadům, volnost stěhování a vystěhování, svobodu osobní, listovní a právo petiční, právo shromažd’ovací a spolčovací, svobodu slova, tisku, víry a svědomí, vědy a volby povolání, ochranu národností a soukromého vlastnictví.

Víře a náboženství jsou v ústavě věnovány v zákonu č. 142 o všeobecných právech občanů státních články 14 až 16, které upravují postavení nejen církví v čl. 15, kde je stanoveno, „každá církev a společnost náboženská zákonem uznaná má právo, náboženství společně a veřejně provozovati, své záležitosti vnitřní o své moci pořádati a spravovati...“ Tato autonomie a nezávislost na správě státní je omezena jen podřízením státním zákonům. Podle článku 16 je přiznáno právo na výkon domácích bohoslužeb i církvím státem neuznaným, s výhradou, že nesmí být protizákonné a porušovat mravnost.

Zásadní změnu přinesl článek 14, který stanovil, že „Svoboda víry a svědomí každému je pojištěna.“ Oddělil práva občanská od náboženství, nebot' stanovil, že ,požívání práv občanských a politických nezávisí na vyznání víry“a že „povinnostem občanským nemůže býti vyznání náboženské na újmu“. Tato ustanovení ústavy musela mít samozřejmě dopad na podobu trestněprávní ochrany církví.

$\mathrm{K}$ novelizaci trestního zákona $\mathrm{z}$ roku 1852 došlo hned v roce 1868 zákonem č. 49/1868 ř. z., článkem 7, který vypustil literu c) a literu d) § 122 trestního zákona „... die Verfüngen des $\S 122$ lit. c) und d) ... sind aufgehoben“. Stalo se tak jedním z tzv. květnových zákonů, z jejich první série, které v duchu liberálních koncepcí nově upravily vztah státu a katolické církve. Dosavadní ustanovení trestního zákona přejímající starou úpravu z roku 1803 o trestnosti vybízení křest’ana k odpadnutí od křest’anské víry stejně jako trestnost rozšiřování nevěry již nemohly být uplatňovány.

Po odstoupení rakouského státu od konkordátu, který byl pak nahrazen zákonem č. 50/1874 ř. z. „O zevních poměrech církve katolické“ a zákonem č. 51/1874 ř. z. byly upraveny příspěvky do náboženského fondu. Oba tyto zákony byly považovány za druhou sérií květnových zákonů. ${ }^{54}$

Trestní zákon z r. 1852 ovšem věnoval pozornost ochraně církve také ještě v II. dílu o přečinech a přestupcích, $v$ hlavě páté „O přečinech a přestupcích proti veřejnému pokoji a řádu, pod lit. e) „Urážka církve nebo náboženské společnosti zákonně uznané“ v $§ 303$.

Tímto ustanovením jsou chráněny církve nebo náboženské společnosti státem uznané před veřejným posmíváním nebo zlehčováním jejich učení, obyčeje, či zřizení, a chrání i jejich „náboženské služebníky“ před urážkami při výkonu jejich bohoslužebních obřadů. Trestem je vězení od jednoho až do šesti měsíců.

Jak je zřejmé, měl tento přečin jen podpůrný účel. V § 304 pak bylo za přečin prohlášeno i jednání, jímž někdo nerespektuje zákaz státní správy a zřizuje nebo rozšiřuje náboženskou společnost nebo sektu, koná jejich shromáždění, přednášky, získává její vyznavače.

53 Tamtéž, s. 219-224.

54 Tamtéž, s. $269-270$ 
Trest stanovený v $\S 304$ od jednoho do tří měsíců mohl být zpřísněn podle $\S 305$, pokud by přečiny uvedené v $\S 303,304$ byly spáchány tiskopisy, na tuhé vězení jednoho roku a vypovězení z místa, a pokud pachateli byli cizinci, mohli být vypovězeni z celého státu.

\section{VII.}

Historické trvání trestání útoků na církev, deliktu rouhání, které jsme sledovali v jeho dlouhém vývoji, tak byl dovršen - Československá republika rakouskou trestněprávní úpravu převzala a uplatňovala ji v meziválečném období s dodatečnou úpravou, kterou přinesl zákon na ochranu republiky č. 50/1923 Sb. z. a n. v § 14 o rušení obecného míru, odst. 2 až 4. Jsou tu postihována jednání označená jako veřejné popuzování k násilnostem nebo záští proti skupinám obyvatel nebo jednotlivci pro jejich národnost, jazyk, rasu nebo náboženství. Tresty jsou odstupňovány podle jednotlivých deliktů. Nejnižší je odnětí svobody na 8 dnů, nejvyšší 2 roky. Později, jak ještě ukážeme, po zrušení zákona na ochranu lidově demokratické republiky č. 231/1948 Sb., který nahradil původní zákon z r. 1923, při kodifikaci nového trestního zákona v roce 1950 byla tato ustanovení do něho včleněna $\mathrm{s}$ tím, že k nim byly připojeny formulace sloužící ochraně nových komunistických pořádků. Konečný zánik trestněprávních předpisů o ochraně církví je tak spojen s kodifikacemi iniciovanými a podniknutými komunistickou vládou v letech 1949-1950, s tzv. právnickou dvouletkou, která odstranila tradice rakouské právní kultury a rakouskou právní úpravu, kterou ČSR v roce 1918 při svém vzniku převzala $\mathrm{z}$ bývalého mocnářství.

V novém trestním zákonu ze dne 12.7. 1950 č. $86 \mathrm{Sb}$. je tak překvapivě církvím a vyznáním věnována řada paragrafü, které však jen zdánlivě připomínají starší právní úpravu. Ve skutečnosti sledují zcela jiné cíle. Tak pod názvem „Útoky proti skupinám obyvatelư“ v $§ 116$ je podle vzoru někdejšího zákona na ochranu republiky z roku 1923 za trestný čin prohlášeno násilí nebo pohrůžky násilí proti skupinám obyvatel republiky „,pro jejich národnost, rasu nebo náboženství anebo proto, že jsou bez vyznání..." Současně je však k této větě připojen text, že stejně jsou chráněni stoupenci lidově demokratického řádu. Tak toto ustanovení nabývá výsostně politický obsah ochrany nového státního řádu nastoleného únorovým převratem. To umocňuje i odstavec 2 tohoto paragrafu, který hovoří o postihu tzv. srocení tří osob. Trest odnětí svobody od jednoho do pěti let může být zvýšen až na deset let, pokud k činu došlo se zbraní nebo za „Zvláště přitěžujících okolností".

Také další § 117 stíhá stejné jednání stejným trestem, pokud je spácháno nikoliv proti skupině obyvatel, ale jednotlivci, trestem jsou tu tři měsíce až dvě léta.

V § 118 je takto stíháno popuzování veřejné nebo „alespoň dvou osob“ k násilnému nebo jinému nepřátelskému jednání proti skupině obyvatel pro jejich národnost, rasu nebo náboženství či že jsou bez vyznání, a opět je tu připojena ochrana lidově demokratického řádu. Trestem je odnětí svobody na tři měsíce až tři léta. V dalším odstavci je stíháno popuzování k zášti a je stíháno trestem odnětí svobody na tři měsíce až dvě léta a konečně, v posledním odstavci tohoto paragrafu, je stíháno jednání výše uvedené proti jednotlivci a trestáno odnětím svobody na jeden rok. Poslední paragraf této části trestního zákonu (§ 119) stíhá veřejné hanobení skupin obyvatel ,pro jejich národnost, rasu nebo náboženství anebo proto, že jsou bez vyznání nebo stoupenci lidově demokratického řádu“ trestem odnětí svobody až na jeden rok. Jak je zřejmé, ochrana náboženského přesvědčení posloužila autorům kodifikace k zakotvení ochrany nových politických pořádků. 
Pokrytecky pak při vědomí toho, co se odehrávalo v letech komunistické vlády, vyznívá ustanovení § 234 o „Omezování svobody vyznání“, kde je stíhán ten, kdo „násilím, pohrůžkou násilí nebo pohrưžkou jiné těžké újmy někoho nutí k náboženskému úkonu nebo mu v tom brání či omezuje jeho uživání náboženské svobody“.

Podstatu a účel nové právní úpravy postavení církví přinesla další ustanovení trestního zákona. V § 173 je stíháno vykonávání duchovenské činnosti bez státního souhlasu trestem odnětí svobody až na tři roky, stejně je postižen výkon duchovenské služby na místě, pro které nebyl státem schválen, a trestem odnětí svobody na jeden rok až pět let je postižen ten, kdo bez souhlasu státu někoho k duchovenské službě ustanoví. A aby nebylo pochybnosti o tom, že stát to myslí vážně, v $§ 174$ je postižen trestem odnětí svobody od jednoho roku do pěti let ten, kdo maří nebo ztěžuje výkon státního dozoru nad církví nebo náboženskou společností nebo porušuje ustanovení zákona o hospodářském zabezpečení církví. V souvislosti s vydáním nového zákona o rodině pak v § 207 je stíhán duchovní, který by nerespektoval ustanovení o povinném civilním sňatku a posvětil manželství, které nebylo již uzavřeno před orgánem státu. Trestem je tu pro duchovního odnětí svobody na jeden rok.

Pozornost církevní problematice nebyla opomenuta ani v trestním zákoně správním ze dne 12. 7. 1950 č. $88 \mathrm{Sb}$. V § 101 pod názvem „Ochrana pořádku ve věcech církevních“ se hrozí trestem pokuty 20.000 Kč nebo vězením v délce tří měsíců za neplnění nebo porušení zákazu týkajícího se právních poměrů církví, zejména však „tomu, kdo poruší výkon státního dozoru nad majetkem církví nebo náboženských společností“.

O mimořádné pozornosti, kterou nový režim věnoval církvím a zřejmé snaze je podrobit státnímu dozoru, svědčí i řada právních aktů z roku 1949, kterými byl zřízen státní úřad pro věci církevní, předpis o hospodářském zabezpečení církví a pět vládních nařízení o hospodářském zabezpečení jednotlivých církví. ${ }^{55}$ Systém zákazů a př́kazů vůči církvím byl tak uzavřen.

Není pochyb o tom, že tato ustanovení trestního zákona nejen že neměla za účel chránit církve a svobodu vyznání, výkon náboženských obřadů a jejich důstojnost, ale naopak církevní instituce přestaly být chráněnými objekty a nová úprava otevírala cestu k úplnému podrobení církví státu, ke ztrátě jejich autonomie, k nevídané perzekuci duchovních i věřících, k ožebračení církví a jejich institucí.

Koncepce ochrany individuálních občanských práv na svobodu vyznání nebo ateismu je východiskem pro současný trestní zákoník č. 40/2009 Sb. ze dne 8. ledna 2009.56

Slovo církev či církve sice v zákoníku nenajdeme, ale o náboženském vyznání se mluví v celé řadě paragrafů, a to v souvislosti s přitěžujícími okolnostmi. Tak v $§ 140$, odst. 3, písm. g) při stanovení trestu za vraždu se považuje za přitěžující okolnost, pokud

55 Dvěma zákony č. 217/1949 Sb. z. a č. 218/1949 Sb. byl zřízen Státní úřad pro věci církevní a předpis o zabezpečení platů duchovních, o nutném státním souhlasu k vykonávání funkce duchovních a o dozoru nad církevním majetkem. 18. října 1949 bylo pak vydáno pět vládních nařízení o platech duchovních, o nutném státním souhlasu k vykonávání funkce duchovních a o dozoru nad církevním majetkem. Téhož dne bylo vydáno pět vládních nařízení č. 219-223 o hospodářském zabezpečení jednotlivých církví. O tom, jaký význam kladla KSČ těmto otázkám, svědčí kromě jiného i to, že předsedou úřadu pro věci církevní se stal zet’ Klementa Gottwalda, Alexej Čepička.

56 Srov. JELÍNEK, J. a kol. Trestní právo hmotné: Obecná část. Zvláštni část. Praha: Leges, 2009, zvl. s. 785 a násl. 
je spáchána „na jiném pro jeho skutečnou nebo domnělou rasu, př́íslušnost k etnické skupině, národnost, politické přesvědčení, vyznání nebo proto, že je skutečně nebo domněle bez vyznání“. Podobná ustanovení, která chrání náboženská vyznání, stejně jako osoby bez vyznání jsou v $§ 146$ stíhajícím ublížení na zdraví, v $§ 170$ u trestného činu zbavení osobní svobody, $\S 183$ u trestného činu porušení tajnosti soukromých listin a jiných dokumentů, v $§ 175$ u deliktu vydírání.

Ochraně náboženského vyznání je věnován $§ 176$, který stíhá toho, „Kdo násilím, pohrůžkou násilí nebo pohrůžkou jiné újmy a) nutí jiného k účasti na náboženském úkonu, b) zdržuje jiného bez oprávnění od takové účasti, nebo c) jinému v užívání svobody vyznání jinak brání, bude potrestán odnětím svobody až na dvě léta." Pokud tento čin spáchá nejméně na třech osobách nebo se zbraní, hrozí mu trest jednoho roku až pět let.

Ochranu náboženskému vyznání poskytuje i $§ 355$, ve kterém je stíháno „hanobení národa, rasy, etnické nebo jiné skupiny osob“, za které je podle odst. 1, písm. b) považována i skupina osob stejného náboženského vyznání nebo bez vyznání. Stejně tak je stíháno „Podněcování k nenávisti vůči skupině osob nebo omezování jejich práv a svobod“ v $§ 356$, kde se výslovně mluví v odst. 1 o podněcování $\mathrm{k}$ nenávisti také vůči náboženství a trestá se takové jednání odnětím svobody až na dvě léta, a podle odst. 3, písm. b) se stíhá trestem od šesti měsíců až tři léta, pokud se pachatel účastní takovým skutkem činnosti skupiny, která hlásá „... náboženskou nebo jinou nenávist“.

O ochraně skupiny lidí vyznávajících náboženství, tedy vlastně církve, se hovoří i v $\$ 400$ o genocidii. Stejně tak v § 401 o útoku proti lidskosti se v odst. 1, písm. e) hovoří o zákazu perzekuce obyvatelstva kromě jiného také na „náboženském základě“.

Ačkoliv se v zákoně výslovně nehovoří o ochraně církví, je náboženské vyznání chráněno jako individuální právo zajištěné kromě jiného i Listinou základních práv a svobod.

Zde, jak se zdá, končí naše cesta za poznáním trestněprávní ochrany církví, institucí, které utvářely naši minulost státní i právní, kulturu, na které spočívá podoba současné západní civilizace. Sledovali jsme jen její právní úpravu a ponechali stranou soudní či správní praxi. Snad však i tento, jistě jen stručný přehled, může být východiskem dalšího zkoumání a nalezení dalších poznatků. 